\title{
METABOLOMIC ANALYSES TO EVALUATE THE EFFECT OF DROUGHT STRESS ON CHILI PEPPER (CAPSICUM ANNUUM L.) AT VEGETATIVE STAGE
}

\author{
Millah Zahratul ${ }^{1,4}$, Syukur Muhamad ${ }^{2,3}$, Sobir $^{2,3}$, Ardie Sintho Wahyuning $^{2}$ \\ ${ }^{1}$ Plant Breeding and Biotechnology Program, Faculty of Agriculture, Graduate School \\ of Bogor Agriculture University, Bogor, West Java, Indonesia \\ ${ }^{2}$ Department of Agronomy and Horticulture, Faculty of Agriculture, \\ Bogor Agriculture University, Bogor, West Java, Indonesia \\ ${ }^{3}$ Center for Tropical Horticulture Studies, Bogor Agriculture University, \\ Bogor, West Java, Indonesia \\ ${ }^{4}$ Department of Agrotechnology, Faculty of Agriculture, Sultan Ageng Tirtayasa University \\ *E-mail: muhsyukur@apps.ipb.ac.id
}

\begin{abstract}
Water shortage due to competition from the various sector, global warming, and climate change leading to less-irrigated field occurred is serious now and future problems for all cultivated plants involving chili pepper. In the situation drought stress give high and significant effect on reducing plant production as a result of alteration in metabolite homeostasis in vegetative tissues. To reveal metabolomic alteration on chili pepper to the stress as main objective of the study, three capsicum genotypes with different tolerance levels to less irrigation condition compared to normal condition were evaluated. Leaves extract of three different chili genotypes grown in less irrigation and normal conditions were analyzed with Gas Chromatography-Mass Spectrophotometry (GC-MS) to reveal profiling of their volatile compounds. Based on principal component analysis (PCA), ten metabolites, i.e., neophytadiene, linolenic acid-ethyl ester, linolenic acid, gamma-sitosterol, phytol, alphatocopherol, squalene, i-propyl 7,10,13,16,19-docosapentaenoate, ergost-5-en-3-ol and bicyclo [10.1.0] tridec-1-ene were known to contribute to the existence of diversities in the three genotypes. Furthermore, under hierarchical cluster analyses (HCA) from the ten metabolite compounds, there were only three important metabolites of linolenic acid, gammasitosterol, and alpha-tocopherol revealing differences of them compared to the normal irrigation plants. In the less irrigated plants, lowering linolenic acid and increasing gammasitosterol and alpha-tocopherol were expressed to response the drought stress. Tolerance chili plants to the stress were affected by their capacity to reduce linolenic acid degradation and to increase alpha-tocopherol and gamma sitosterol accumulation.
\end{abstract}

\section{KEY WORDS}

Capsicum annuum, drought stress, GC-MS, volatile compound, vegetative stage.

Chilli pepper (Capsicum annuum L.) is one of important and strategic commodities in Indonesia giving a significant effect on the dynamic Indonesian economy and its inflation. In one hand, the high economic value is performed by total cultivation areas reaching 308,547 ha with Central, West and East Java provinces as main cultivation areas; 2.5 million ton total production 2018; 7.78 tonnes/ha productivity (BPS 2019) and high dynamic prices from Rp.4,000 to 120,000 per $\mathrm{kg}$ (Republika 2019). On the other hand, Kompas (2021) published that inflation index of consumer price in January 2021 was $0.21 \%$ caused by administered prices and volatile food. one of the biggest contributors to inflation is chili pepper. Though the chili pepper has high economic value and gives serious problem in Indonesian economic stability, there is difficult task, especially in balancing between its supply and demand. There is a big problem faced in maintaining and sustaining high plant productivity, especially in the dry season due to drought stress occurred during cultivation of the plants. For the chili pepper plants that have highly sensitive to the stress, drought condition generally decreased the plant production drastically. 
In cultivation aspects, the chili plants are plants that require much water for their growth and are sensitive to irrigation practices (Abdul-Ganiyu et al. 2012). Lack of water in the plants can cause drought stress leading to a very significant yield loss (Gençoğlan et al., 2006; Demirtas and Ayas, 2009). Drought stress generally affected physiological, biochemical, and molecular processes such as photosynthesis, respiration, translocation, and metabolism (Pandey and Shukla, 2015). The stress interferes metabolite homeostasis and causes significant chemical composition changes in plants which require the temporal readjustments of the metabolic pathway (Azadeh et al. 2014), including carbohydrate, amino acid, and peptide metabolism (Huang and Gao 2000) and altering the metabolomic profiles of leaf tissues (source) that could reduce its yield (sink) potential. Furthermore, revealing chili metabolomic profile, especially in determination tolerance levels of the plants to drought stresses is important information for breeding programs, especially to establish selected tolerance candidates.

Several plant metabolomic profile studies were successfully reported previously. Wahyuni et al. (2013) found that a large group of acyclic diterpenoid glycosides, called capsianosides, was in highly abundant in all $C$. annuum genotypes studied. Metabolomic profiling demonstrated that in soybeans, keeping up with sugar and nitrogen metabolism is of prime significance, along with phytochemical metabolism under drought and heat stress conditions (Das et al., 2017). In African eggplant, proline, glutamate, sucrose, fructose and tricarboxylic acid cycle metabolites were shown to be positively correlated with stress (Mibei et al., 2017). In sugar beets, drought triggered changes in primary metabolism, especially increases in amino acids in both organs, but leaves and roots responded with different dynamics to re-watering. After a transient normalization of most metabolites within eight days, a second accumulation of amino acids in leaves might indicate a stress imprint beneficial in upcoming drought events (Wedeking et al., 2018). While metabolomic profiling on Capsicum annuum $\mathrm{L}$ dealing with the establishment tolerance level of chili pepper is not reported yet.

In the study, important information was successfully revealed based on comparing three selected chili genotypes in different tolerance levels to drought stress with the normal genotype as the main objective of the research. Results of the study gave evidence that different level of tolerances on chili pepper was affected by the existence of linolenic acid, gamma-sterol, and alpha-tocopherol. The metabolomic profiling of chili pepper according to its response to drought, was discussed in detail in this paper.

\section{MATERIALS AND METHODS OF RESEARCH}

The experiment used Gada MK, SSP, and C10 genotypes which were collections of the Laboratory of Genetic-Education and Plant-Breeding, IPB. The selection of genotypes was based on tolerance level grouping by Fischer and Maurer (1978) on vegetative and yield characters. Gada MK and SSP represent tolerant genotypes, whereas C10 represents sensitive genotypes.

The seeds of 3 chili genotypes were germinated in trays containing a mixture of soil and compost as sowing media. After four weeks of sowing or have at least four adult leaves, the seedlings were transplanted to polybags (30 $\mathrm{cm}$ in diameter) containing a mixture of soil, sand, and manure $(2: 2: 1, \mathrm{v} / \mathrm{v} / \mathrm{v})$. Before mixing, each component of the media is filtered with a $0.5 \mathrm{~cm}$ diameter hole sieve to obtain fine granules, uniform and free of impurities, then dried. The polybags filled with soil are then saturated with water. Planting was done in the afternoon (one plant per polybag). The chili plants were then placed in the greenhouse and arranged in rows with a distance of $50 \mathrm{~cm} \times 50 \mathrm{~cm}$ and a distance between treatments 70 $\mathrm{cm}$. Normal irrigation was maintained before and three weeks after transplanting of the seedlings to keep the soil moisture at over $90 \%$ field capacity.

The experiment consisted of two treatments, i.e., full irrigation (as control) and less irrigation (drought), arranged in randomized complete block design with three replications. Drought treatment was started at three weeks after transplant applied by stopping irrigation in 7 days. Soil moisture measurement was carried out every day using a soil moisture sensor 
based on electrical impedance, and the humidity of media was maintained at the range of 50 $60 \%$ field capacity.

Metabolomics analysis was conducted using Agilent Technologies 7890 GC system with Auto Sampler, 5975 Mass Selective Detector and Chemstation data, which was equipped with a capillary column HP Ultra 2 (30 m x 0.20 mm ID x 0:11 $\mu \mathrm{m}$ Film Thickness). Samples were taken from each treatment one week after the application of the treatments (four weeks after transplant or at the end of the vegetative period). Fresh leaves $(10 \mathrm{~g})$ from each treatment were sliced into small pieces and extracted with pro analysis ethanol $(50 \mathrm{~mL})$ then macerated for approximately five days in a closed container at room temperature. After maceration, $10 \mathrm{ml}$ of the extract was poured into the tube and then dried at $60^{\circ} \mathrm{C}$ for 1 hour. After drying, the extract was dissolved again with the remaining $200 \mu \mathrm{L}$ extracts and use as a sample in GC-MS analysis. Each component of metabolites was identified by matching the recorded mass spectrum from the GC-MS data system. Metabolite components were identified by the name of the compound, molecular formula, and molecular weight using a peak spectrum comparison in Wiley and PubChem databases.

Data were analyzed statistically by using the R package (Xia and Wishart, 2016). Principal Component Analysis (PCA) was applied to determine the metabolites that contribute significantly to the diversity of chili genotypes. Hierarchical Cluster Analysis (HCA) was conducted to assess the relationship between chili genotypes in response to normal and drought conditions. The t-Students test was conducted to show metabolite differences between treatments.

\section{RESULTS AND DISCUSSION}

A total of 83 volatile compounds identified from three chili genotypes grew under normal and drought conditions based on PCA (Table 1). From the 83 volatile compounds, 20 metabolites gave most contribution in forming diversity (Figure 1), however, only 10 metabolites, i.e: neophytadiene, linolenic acid-ethyl ester, linolenic acid, gamma -sitosterol, phytol, Alpha-tocopherol, squalene, i-Propyl 7,10,13,16,19-docosapentaenoate, Ergost-5-en3-ol and Bicyclo [10.1.0] tridec-1-ene can differentiate genotypes based on the treatments applied (Figure 2 and 3). Furthermore, under HCA from the ten metabolites (Figure 3), there were three important volatile compounds detected in leaf samples derived from normal and drought stress condition, namely linolenic acid (M5), gamma-sitosterol (M9) and alphatocopherol (M15). This result was then confirmed by the T-Student test at the level of $5 \%$. All chili samples grew in drought conditions showed a decrease in linolenic acid levels, and an increase in gamma-sitosterol and alpha-tocopherol (Figure 4).

At normal growth condition, the highest linolenic acid content was recorded at the C10 as sensitive genotype and indicated significant difference compared to the Gada and SSP as tolerant genotypes (Figure 5a). The highest content of alpha-tocopherol during normal condition was also expressed by $\mathrm{C} 10$ genotype, but there was no significant difference compared to Gada and SSP genotypes (Figure 5b) while the lowest gamma-sitosterol content in the normal condition was noted in the C10 genotype and indicated significant difference compared to the Gada and SSP as tolerant genotypes (Figure 3c).

Under drought stress conditions, in sensitive genotypes (C10) there was a significant decrease in linolenic acid content with a slight increase in alpha-tocopherol and gammasitosterol content, whereas in tolerant genotypes (SSP and Gada MK) there was no significant decrease in linolenic acid content, but a significant increase in alpha-tocopherol and gamma-sitosterol content (Table 2). Table 2 was strengthened by the change concentration of the three important metabolites (Figure 6).

Entirely the study successfully revealed evident that different growth of chili pepper in normal and drought stress condition leading to different metabolite compound profiling. All chili samples grew in drought conditions showing a decrease in linolenic acid and an increase in alpha-tocopherol and gamma-sitosterol levels. 
Table 1 - The concentration of volatile compounds derived from the leaf samples of three chili genotypes at normal and less irrigation condition

\begin{tabular}{|c|c|c|c|c|c|c|c|c|c|c|c|}
\hline \multirow{3}{*}{ No } & \multirow{3}{*}{ Label } & \multirow{3}{*}{ Compounds } & \multirow{3}{*}{ Molecular Formula } & \multirow{3}{*}{$\begin{array}{l}\text { Molecula } \\
\mathrm{r} \text { Weight } \\
(\mathrm{g} / \mathrm{mol})\end{array}$} & \multirow{3}{*}{$\begin{array}{l}\text { Retention } \\
\text { Time }\end{array}$} & \multicolumn{6}{|c|}{ Peak area $(\%)$ of Chilli genotypes } \\
\hline & & & & & & \multicolumn{3}{|c|}{ Normal Condition } & \multicolumn{3}{|c|}{ Drought Condition } \\
\hline & & & & & & SSP & $\begin{array}{l}\text { Gad } \\
\text { a }\end{array}$ & $\mathrm{C} 10$ & SSP & Gada & C10 \\
\hline 1 & M1 & Neophytadiene & $\mathrm{C} 2 \mathrm{OH} 38$ & 278.52 & 27.37 & 8.35 & 9.05 & 4.28 & 16.79 & 10.71 & 8.27 \\
\hline 2 & M65 & 6,10-Dimethyl-9-Undecen-2-One & $\mathrm{C} 13 \mathrm{H} 24 \mathrm{O}$ & 196.33 & 27.42 & 0.00 & 0.36 & 0.00 & 0.00 & 0.00 & 0 \\
\hline 3 & M77 & 1-Hexadecyne & $\mathrm{C} 16 \mathrm{H} 30$ & 222.42 & 27.46 & 0.00 & 0.00 & 0.70 & 0.00 & 0.00 & 0 \\
\hline 4 & M16 & 6-Tetradecyne & $\mathrm{C} 14 \mathrm{H} 26$ & 194.36 & 27.62 & 0.00 & 0.00 & 0.00 & 0.00 & 0.00 & 0 \\
\hline 5 & M66 & 1,E-8,Z-10-Tridecatriene & $\mathrm{C} 13 \mathrm{H} 22$ & 178.32 & 27.62 & 0.00 & 0.30 & 0.00 & 0.00 & 0.00 & 0 \\
\hline 6 & M17 & 1- Bromo-8-Heptadecyne & $\mathrm{C} 17 \mathrm{H} 31 \mathrm{Br}$ & 315.34 & 27.79 & 0.00 & 0.50 & 0.00 & 0.00 & 0.00 & 0 \\
\hline 7 & M42 & Sclaral (Sclareolide Lactol) & $\mathrm{C} 16 \mathrm{H} 28 \mathrm{O} 2$ & 252.40 & 28.08 & 6.08 & 0.00 & 1.67 & 0.00 & 0.00 & 0 \\
\hline 8 & M62 & 2,2,7-Trimethyl-3-octyne & $\mathrm{C} 11 \mathrm{H} 20$ & 152.28 & 28.09 & 0.00 & 3.93 & 0.00 & 0.00 & 0.00 & 0 \\
\hline 9 & M18 & .alpha.-Selinene & $\mathrm{C} 15 \mathrm{H} 24$ & 204.36 & 28.50 & 0.00 & 0.00 & 0.00 & 0.00 & 0.00 & 0 \\
\hline 10 & M43 & i-Propyl 7,10,13,16,19-docosapentaenoate & & & 28.51 & 0.54 & 0.00 & 0.00 & 0.93 & 0.00 & 0 \\
\hline 11 & M74 & 1,5-Cyclodecadiene, $(\mathrm{E}, \mathrm{Z})_{-}$ & $\mathrm{C} 10 \mathrm{H} 16$ & 136.24 & 28.60 & 0.00 & 0.00 & 0.00 & 0.00 & 2.85 & 0 \\
\hline 12 & M80 & 1-Cyclododecyne & $\mathrm{C} 12 \mathrm{H} 2 \mathrm{O}$ & 164.29 & 28.61 & 0.00 & 0.00 & 1.61 & 0.00 & 0.00 & 0 \\
\hline 13 & M70 & $\begin{array}{l}\text { Acetamide, N-(IMIDAZOL-1-ylpropyl)-2- } \\
\text { Methoxy }\end{array}$ & & & 28.61 & 0.00 & 0.00 & 0.00 & 0.00 & 1.94 & 0 \\
\hline 14 & M26 & Stearate & $\begin{array}{l}\mathrm{CH} 3(\mathrm{CH} 2) 16 \mathrm{COOH} \text { or } \\
\mathrm{C} 18 \mathrm{H} 36 \mathrm{O} 2\end{array}$ & 284.48 & 28.72 & 0.00 & 0.00 & 0.00 & 0.00 & 0.00 & 0 \\
\hline 15 & M3 & Palmitic Acid & $\mathrm{C} 16 \mathrm{H} 32 \mathrm{O} 2$ & 256.43 & 28.78 & 8.24 & 9.83 & $\begin{array}{l}11.5 \\
8\end{array}$ & 6.44 & 8.33 & 7.24 \\
\hline 16 & M48 & Palmityl Chloride & $\mathrm{C} 16 \mathrm{H} 33 \mathrm{Cl}$ & 260.89 & 29.48 & 0.00 & 0.00 & 0.00 & 0.34 & 0.54 & 0 \\
\hline 17 & M52 & 3-Tetradecene & $\mathrm{C} 14 \mathrm{H} 28$ & 196.38 & 29.48 & 0.00 & 0.00 & 0.00 & 0.60 & 0.00 & 0 \\
\hline 18 & M57 & Cyclododecane & $\mathrm{C} 12 \mathrm{H} 24$ & 168.32 & 29.48 & 0.00 & 0.00 & 0.00 & 0.58 & 0.00 & 0 \\
\hline 19 & M83 & Cyclohexadecane, 1,2-diethyl- & $\mathrm{C} 2 \mathrm{OH} 40$ & 280.54 & 29.48 & 0.00 & 0.00 & 0.00 & 0.00 & 0.00 & 0.36 \\
\hline 20 & M10 & Phytol & $\mathrm{C} 2 \mathrm{OH} 40 \mathrm{O}$ & 296.54 & 29.50 & $\begin{array}{l}10.0 \\
3\end{array}$ & 6.66 & 7.31 & 35.44 & 7.16 & 6.35 \\
\hline 21 & M75 & Phytol Isomer & $\mathrm{C}_{20} \mathrm{H}_{40} \mathrm{O}$ & 296.53 & 29.54 & 0.00 & 0.00 & 0.00 & 0.00 & 6.78 & 0 \\
\hline 22 & M4 & benzyl (dideuterated) methyl Ethe & & & 29.56 & 0.00 & 0.00 & $\begin{array}{l}15.9 \\
2\end{array}$ & 0.00 & 14.51 & 0 \\
\hline 23 & M39 & $\begin{array}{l}\text { Cyclodecacyclotetradecene, } \\
1,2,3,4,5,6,7,8,9,10,11,12,13,14,15,16,17,18,1 \\
9,20 \text {-eicosahydro- }\end{array}$ & $\mathrm{C} 22 \mathrm{H} 40$ & 304.56 & 29.62 & 0.30 & 0.00 & 0.00 & 0.00 & 0.00 & 0 \\
\hline 24 & M44 & 1,4,9-Decatriene, $(\mathrm{Z})$ - & $\mathrm{C}_{10} \mathrm{H}_{16}$ & 136.238 & 29.62 & 0.29 & 0.00 & 0.00 & 0.00 & 0.00 & 0 \\
\hline 25 & M60 & $\begin{array}{l}\text { 6-[1-(Hydroxymethyl)Vinyl]-4,8a-Dimethyl- } \\
\text { 4a,5,6,7,8,8a-Hexahydro-2(1h)-Naphthalenone }\end{array}$ & $\mathrm{C}_{15} \mathrm{H}_{22}$ & 234.334 & 29.63 & 0.00 & 0.34 & 1.67 & 0.00 & 0.00 & 0 \\
\hline 26 & M63 & 1,2-15,16-Diepoxyhexadecane & $\mathrm{C} 16 \mathrm{H} 30 \mathrm{O} 2$ & 254.41 & 29.63 & 0.00 & 0.33 & 0.00 & 0.00 & 0.00 & 0 \\
\hline
\end{tabular}


Table 1 Continue

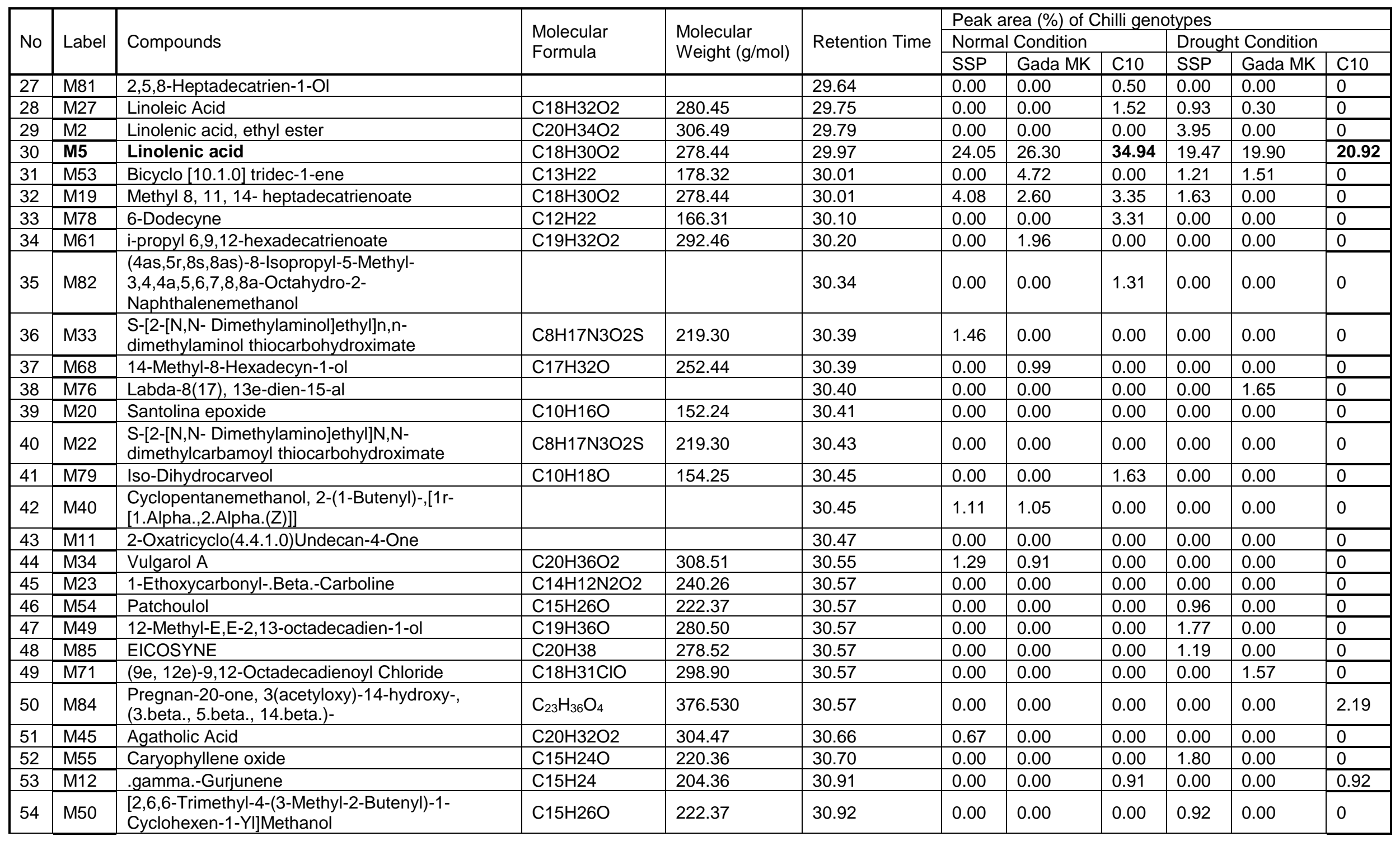


Table 1 Continue

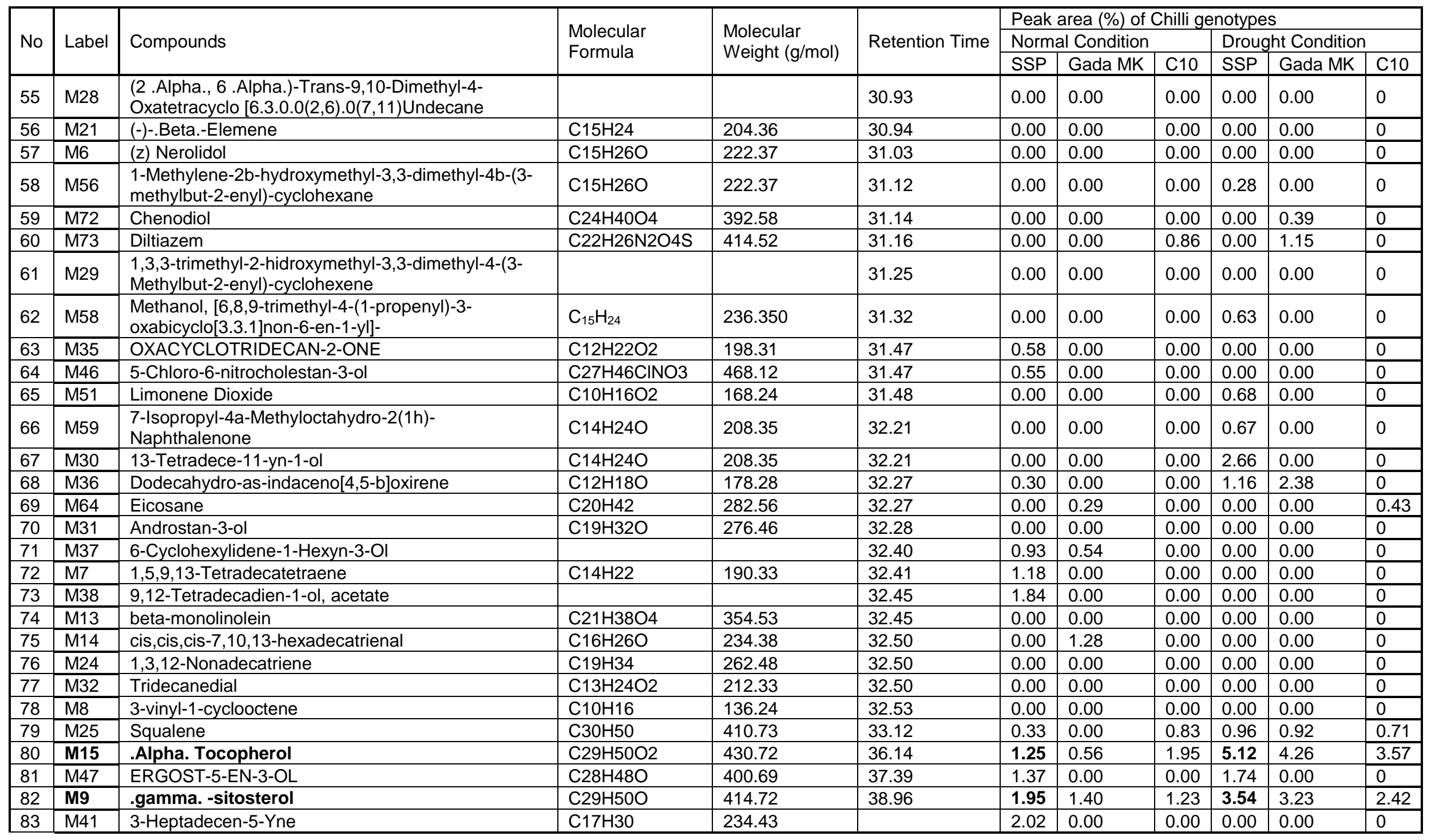



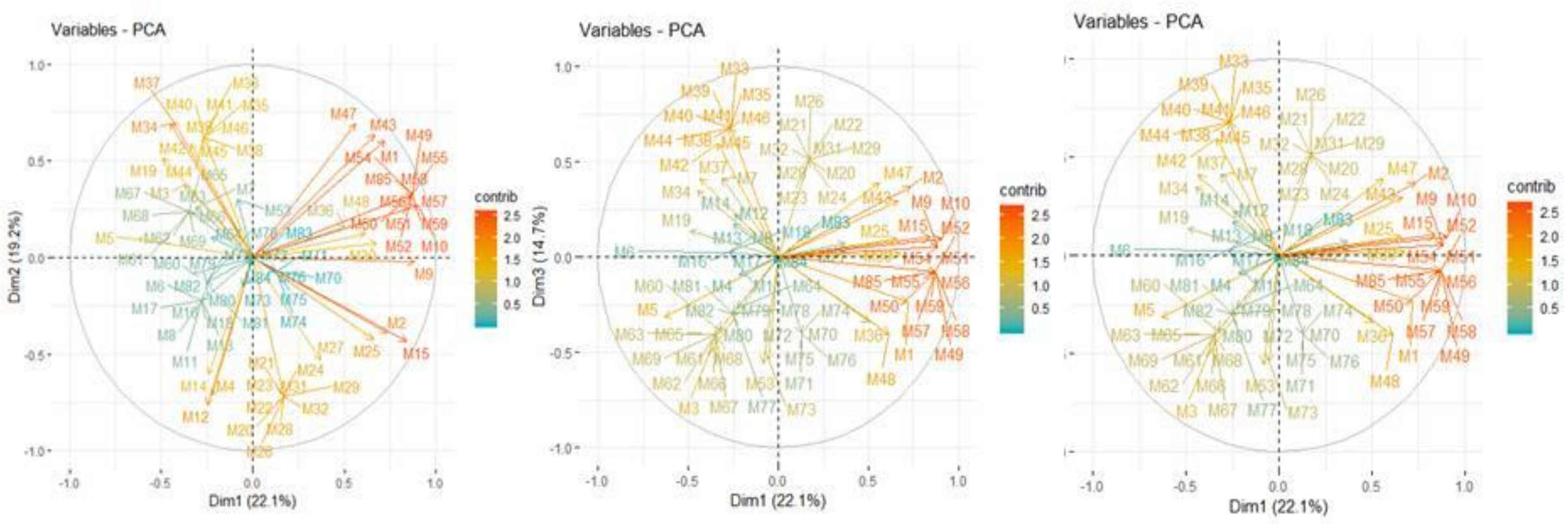

Figure 1 - Biplot of 83 volatile compounds from the leaf samples of three chili genotypes at normal and less Irrigation Condition 
Contribution of variables to Dim-1

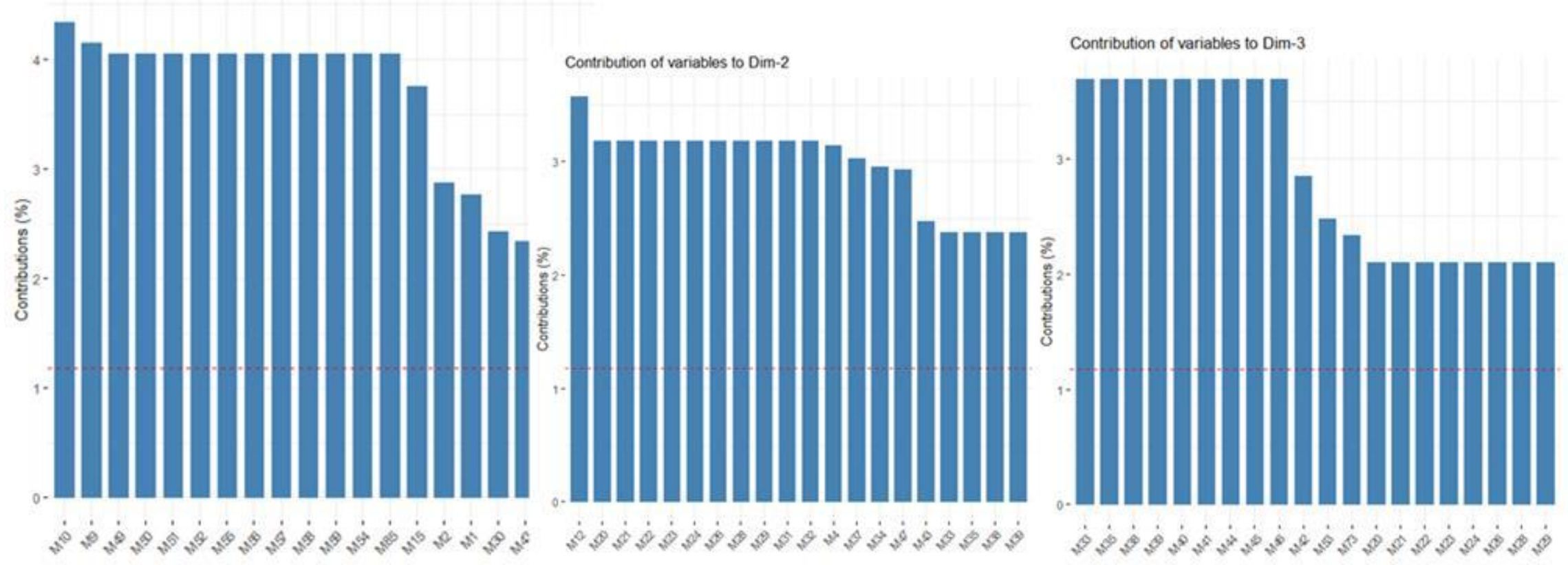

Figure 2 - Graphic of the contribution of metabolite at PC1, PC2, and PC3 


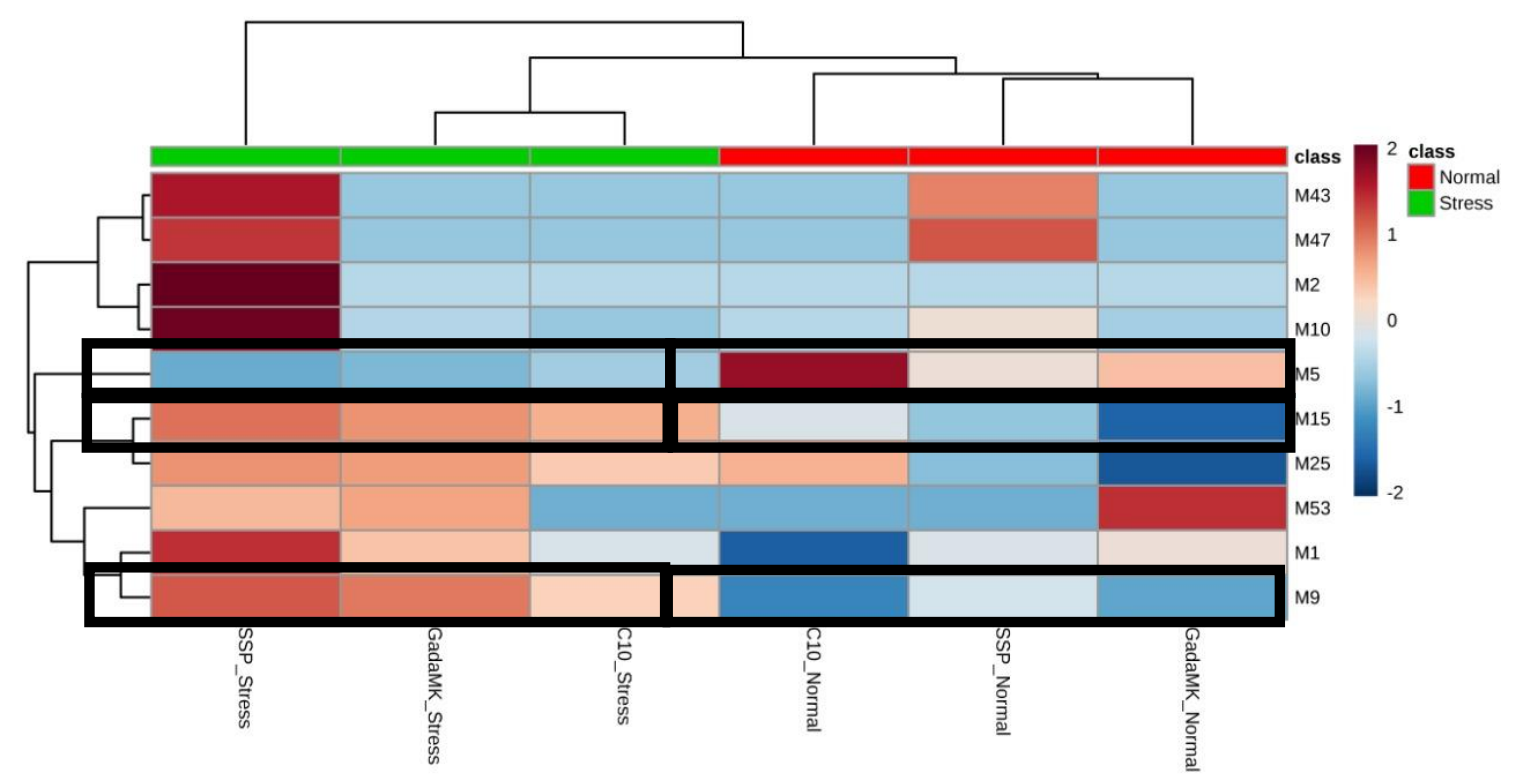

Figure 3 - Heatmap of 10 metabolite compounds from leaf samples of three chili genotypes at normal and drought stress conditions.

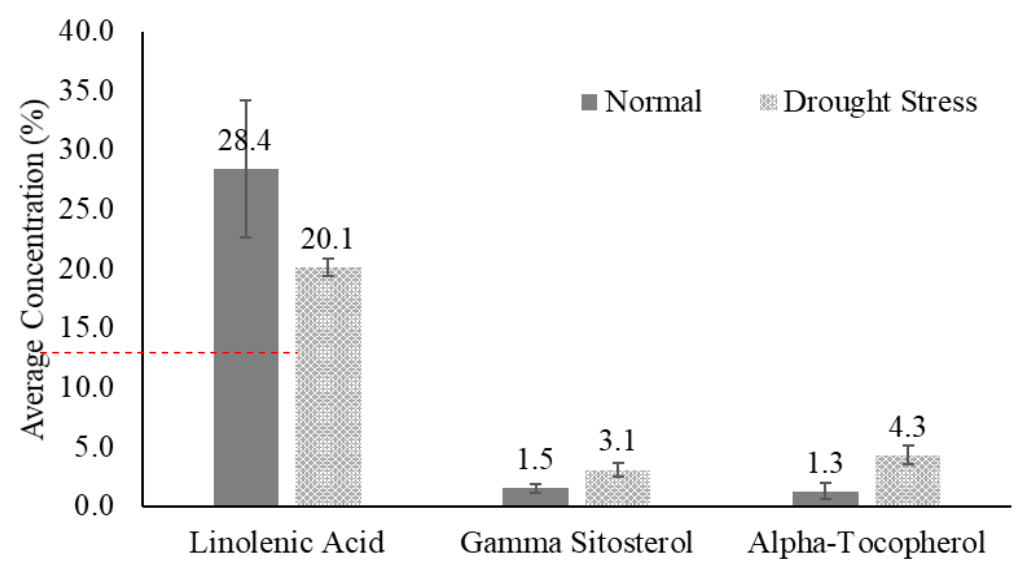

Figure 4 - The average concentration_of_metabolite_compounds that show_differences in chili leaf samples grown under normal and drought conditions.

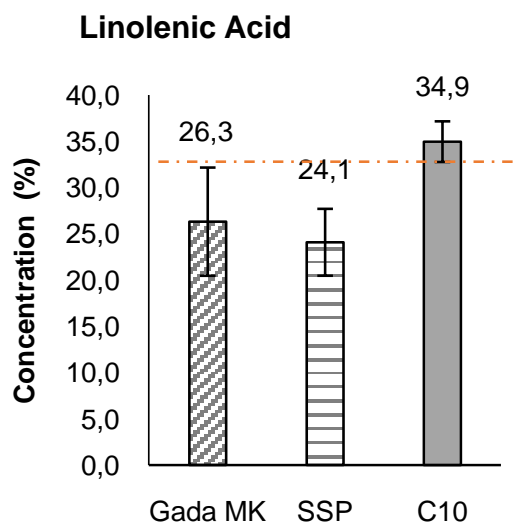

(a)

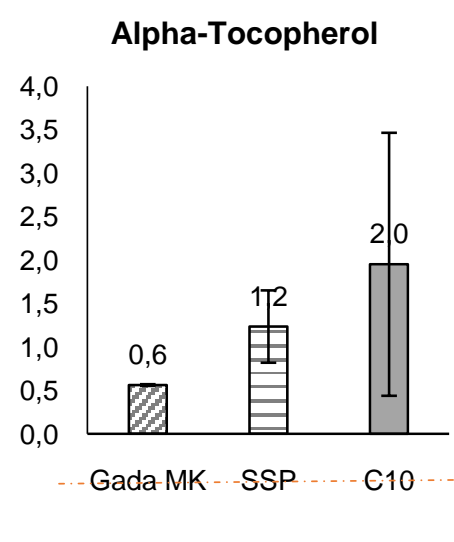

(b)

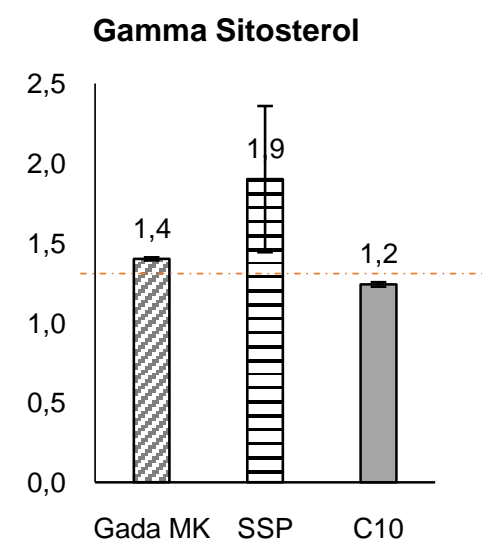

(c)

Figure 5 - The linolenic acid content (a), Alpha Tocopherol (b) and Gamma sitosterol,

(c) in the Gada MK, SSP and C10 genotypes under normal condition 
Table 2 - The concentration of metabolites in Gada MK (tolerant), SSP (tolerant) and C10 (sensitive) genotypes under normal and drought conditions

\begin{tabular}{|c|c|c|c|c|}
\hline \multirow[b]{2}{*}{ Genotype } & \multirow[b]{2}{*}{ Metabolites } & \multicolumn{2}{|c|}{ Average concentration (\%) } & \multirow[b]{2}{*}{$\operatorname{Pr}>|\mathrm{t}|$} \\
\hline & & $\begin{array}{l}\text { Normal } \\
\text { (Sufficient Irrigation) }\end{array}$ & $\begin{array}{l}\text { Drought } \\
\text { (Less Irrigation) }\end{array}$ & \\
\hline \multirow{3}{*}{ Gada MK } & Linolenic acid & 26.3 & 19.9 & 0.192 \\
\hline & Alpha-Tocopherol & 0.6 & 4.3 & $0.001^{\star *}$ \\
\hline & Gamma-sitosterol & 1.4 & 3.2 & 0.009 ** \\
\hline \multirow{3}{*}{ SSP } & Linolenic acid & 24.1 & 19.5 & 0.233 \\
\hline & Alpha-Tocopherol & 1.2 & 5.1 & $0.001^{\star \star}$ \\
\hline & Gamma-sitosterol & 1.9 & 3.5 & 0.035 * \\
\hline \multirow{3}{*}{ C10 } & Linolenic acid & 34.9 & 20.9 & $0.004^{\star \star}$ \\
\hline & Alpha-Tocopherol & 2.0 & 3.6 & 0.490 \\
\hline & Gamma-sitosterol & 1.2 & 2.4 & 0.018 * \\
\hline
\end{tabular}

Note: ${ }^{*}=$ significant at $\alpha=0.05 ;{ }^{* *}=$ very significant at $\alpha=0.05$.

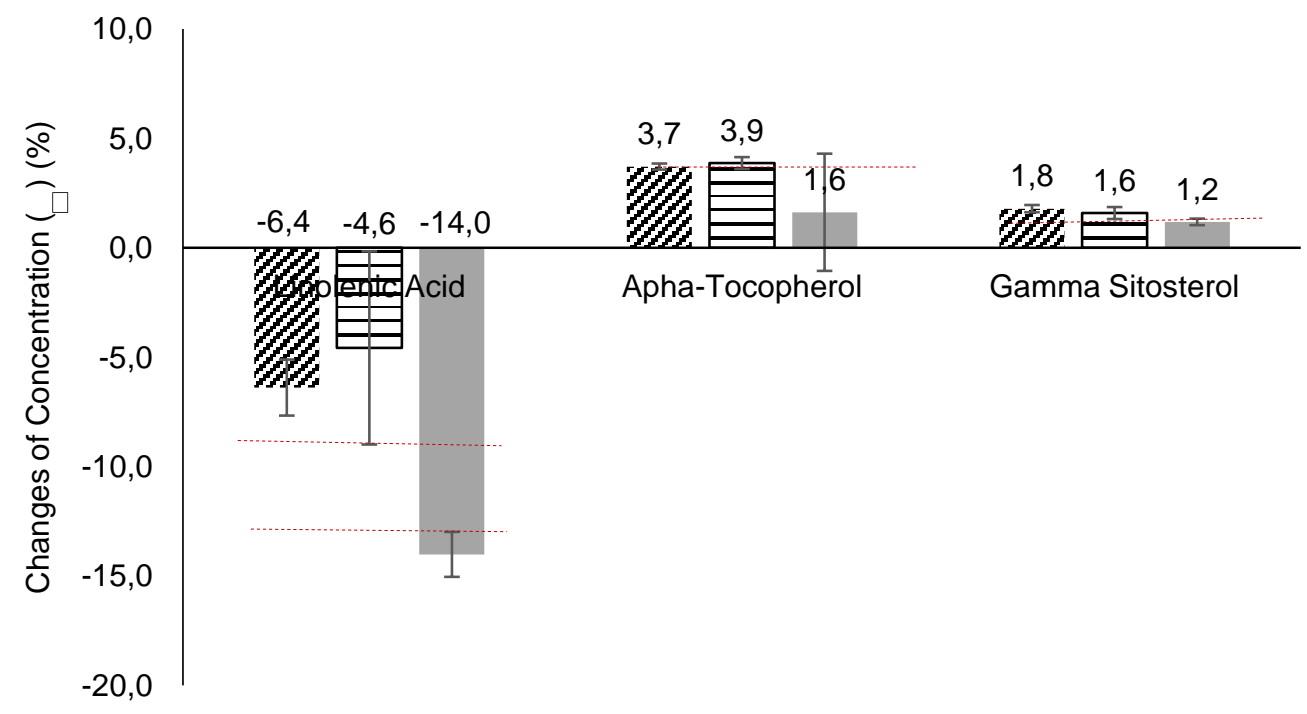

o Gada MK =SSP $=\mathrm{C} 10$

Figure 6 - Response in concentration changes $(\Delta)$ of linolenic acid, alpha-tocopherol, and gammasitosterol in each chili genotype due to drought condition

The results of our study concur with the findings of other studies that have reported a decrease in linolenic acid content (Pham Thi et al., 1987; Pham Thi et al., 1990; Repellin et al. 1997), an increase in phytosterol content (Kumar et al. 2015), and an increased in alphatocopherol content ( Tanaka et al., 1990; Moran et al., 1994; Price et al., 1989; Bartoli et al., 1999; Munn'e-Bosch et al., 1999; Munn'e-Bosch and Alegre, 2001) in plants response to drought stress.

Pham Thi et al. (1990) and Repellin et al. (1997) stated that tolerant plants tend to contain less linolenic acid than sensitive plants. Cowpea (Vigna unguiculata) and cotton (Gossypium hirsutum) which are tolerant to drought contain smaller amounts of polar lipids and MGDG and higher saturation levels of MGDG because the content of linolenic acid is less than sensitive plants at normal conditions (Pham Thi et al. 1990). This previous study similar to our study, where linolenic acid content in sensitive genotype (C10) is higher than in tolerant genotypes (Gada and SSP). C10 genotype contains the highest, and significantly different linolenic acid content compared to Gada and SSP genotypes at normal condition.

The previous study shows that the percentage of linolenic acid in the droughtsusceptible variety of cowpea and cotton significantly decreases when exposed to drought, while in the drought-tolerant variety it is only slightly decreasing or does not vary (Pham Thi et al., 1990). In accordance with the previous results, in this study, there was a significant 
decrease in linolenic acid content in sensitive genotype (C10) when exposed to drought, whereas in resistant genotypes (Gada MK and SSP) there was no significant decrease in linolenic acid content (Table 2.)

The increase in gamma-sitosterol as one of the phytosterols in chili plants exposed to drought in this study is similar to some previous studies in other plants. Kumar et al. (2015) reported that in rice plants exposed to drought stress there was an increase in phytosterol, and the tolerant cultivars ability to survive in drought condition are due to its better ability to accumulate phytosterols rather than susceptible cultivars. In this study gamma-sitosterol content were significantly increased in the three genotypes when exposed to drought, but it seems that tolerant genotypes (Gada MK and SSP) accumulate gamma-sitosterol better than sensitive genotype (C10) (Figure 6.)

Studies in different plants have shown a positive relationship between biosynthesis/tocopherol accumulation and water stress (Munn'e-Bosch et al., 1999; Munn'eBosch and Alegre, 2003). Some Reports have shown a remarkable increase in alphatocopherol in conditions of water shortages in pea (Tanaka et al., 1990; Moran et al., 1994), wheat and cereals (Price et al., 1989; Bartoli et al., 1999), rosemary (Munn'e-Bosch et al., 1999), and lavender (Munn'e-Bosch and Alegre, 2001). In accordance with the results of these studies, our study also showed an increase in alpha-tocopherol content in chili plants at conditions of water shortages.

In a recent report, Kumar et al. (2013) observed that alpha-tocopherol-enriched transgenic Brassica juncea plants constitutively overexpressing the $\mathrm{Y}$-TMT gene showed enhanced tolerance to drought stress compared to wild-type plants. Hasanuzzaman et al. (2014) stated that the elevated level of alpha-tocopherol might enhance the photosynthetic efficiency and lower lipid peroxidation leading to better oxidative protection. According to this statement, in this study, there was a very significant increased of alpha-tocopherol content in tolerant genotypes (Gada MK and SSP) (Table 2. and figure 6.) and only slightly increased of this metabolite in the sensitive genotype (C10).

From this study, it was revealed that maintaining linolenic acid contents and increasing alpha-tocopherol and gamma-sitosterol recorded in Gada MK and SSP genotypes were a mechanism for both genotypes to respond and adapt to the drought stress condition.

\section{CONCLUSION}

Our study showed evidence of drought stress responses in chili pepper, as indicated by a decreased level of linolenic acid, and increased levels of alpha-tocopherol and gammasitosterol. The study displayed differences in the levels of linolenic acid, alpha-tocopherol, and gamma-sitosterol in response to drought stress, and this was dependent on genotype.

Genotypes that are tolerant to drought stress (Gada and SSP) produce a low level of linolenic acid in normal condition and have not significantly decreased in content when exposed to drought. The tolerant genotypes produce high gamma sitosterol and alphatocopherol in normal condition and also had a significant increase in content when exposed to drought.

\section{REFERENCES}

1. Abdul-Ganiyu S, Amaanatu MK, Korese JK. 2012. Crop water use and productivity for pepper (Capsicum frutescens) production in the bontanga irrigation scheme of northern region of ghana. Int J of Agric Sci and Bioresource Engine Res. 1 (2): 43-50.

2. Azadeh R, Maryam F, Saeed S. The effects of seed priming by ascorbic acid on some morphological and biochemical aspects of rapeseed (Brassica napus I.) under drought stress condition. 2014. Int J Biosci. 4: 432-442.

3. Bartoli CG, Simontacchi M, Tambussi E, Beltrano J, Montaldi E, Puntarulo S. 1999. Drought and watering-dependent oxidative stress: effect on antioxidant content in Triticum aestivum L. leaves. J. Exp. Bot. 50: 375-383. 
4. [BPS] Badan Pusat Statistik. 2019. Statistik Indonesia 2019. Jakarta (ID). Subdirektorat Publikasi dan Kompilasi Statistik. Balai Pusat Statistik.

5. Burgess P, Huang B, Gianfagna T. 2013. Fatty acid metabolism in leaves and roots associated with improved drought tolerance in agrostis stolonifera expressing sag12-ipt gene controlling cytokinin synthesis. Int Turfgrass Soc Res J. 12: 497-502.

6. Clark R, Lee SH. 2016. Anticancer properties of capsaicin against human cancer. Anticancer Res. 36(3): 837-843.

7. Dakhma WS, Zarrouk M, Cherif A. 1995. Effects of drought-stress on lipids in rape leaves. Phytochem.40 (5): 1383-1386.

8. Republika. 2019. Harga Cabai Anjlok, Petani Minta Harga Acuan Ditentukan. Republika Online. Retrieved from [https://www.republika.co.id/berita/ekonomi/pertanian/pt496a370]

9. Das A, Rushton PJ, Rohila JS. 2017. Metabolomic Profiling of Soybeans (Glycine max L.) Reveals the Importance of Sugar and Nitrogen Metabolism under Drought and Heat Stress. Plants $6(21)$

10. Demırtas C, Ayas S. 2009. Deficit irrigation effects on pepper (Capsicum annuum L. Demre ) yield in unheated greenhouse condition. J of Food, Agric \& Env. 7 (3\&4) : 989993.

11. Fischer RA, Maurer R. 1978. Drought resistance in spring wheat cultivars: I. Grain yield responses. Aust J Agric Res. 29: 897-912.

12. Gençoğlan C, Akinci IE, Ucan K, Akinci S, Gençoğlan S. 2006. Response of red hot pepper plant (Capsicum annuum $L$ ) to the deficit irrigation. Akdeniz Uuniversiteisi Zirrat Fakultesi Dergisi 19: 131-138.

13. Hartmann M. 1998. Plant sterols and the membrane environment. Trends in Plant Sci. 3(5): 170-175.

14. Hasanuzzaman M, Nahar K, Fujita M. 2014. Role of Tocopherol (Vitamin E) in Plants: Abiotic Stress Tolerance and Beyond in Emerging Technologies and Management of Crop Stress Tolerance. Edited by: Parvaiz Ahmad and Saiema Rasool. Volume 2: A Sustainable Approach. Pages 267-289.

15. Huang B, Gao H. 2000. Growth and carbohydrate metabolism of creeping bentgrass cultivars in response to Increasing temperatures. Crop Sci. 40: 1115-1120

16. Jorge TF, Rodrigues JA, Caldana C, Schmidt R, van Dongen JT, Oates JT. 2016. Mass spectrometry-based plant metabolomics: Metabolite responses to abiotic stress. Mass Spectrom Rev. 35: 620-649.

17. Kompas. 2021. Inflasi Januari 0,26 Persen, Harga Cabai Rawit hingga Tahu-Tempe Jadi Pendorong. Kompas online. Retrieved from [https://money.kompas.com/

18. Kumar MSS, Ali K, Dahuja A, Tyagi A. 2015. Role of phytosterols in drought stress tolerance in rice. Plant Physiol and Biochem. 96:83-89.

19. Moran JF, Becana M, Iturbeormaetxe I, Frechilla S, Klucas RV, Apariciotejo P. 1994. Drought induces oxidative stress in pea-plants. Planta 194: 346-352.

20. Munne-Bosch S, Alegre L. 2002. The function of tocopherols and tocotrienols in plants. Critical Rev in Plant Sci. 21(1):31-57.

21. Munne-Bosch S. 2005. The role of $\alpha$-tocopherol in plant stress tolerance. J of Plant Physiol. 162:743-748.

22. Pandey V, Shukla A. 2015. Acclimation and tolerance strategies of rice under drought stress. Rice Sci. 22(4): 147-161.

23. Pham Thi AT, Borrel-Flood C, da Silva JV, Justin AM, Mazliak P. 1985. Effects of Water Stress on Lipid Metabolism in Cotton Leaves. Phytochem. 24(4): 123-127.

24. Pham Thi AT, Borrel-Flood C, da Silva JV, Justin AM, Mazliak P. 1987. Effects of drought on $\left[1-{ }^{14} \mathrm{C}\right]$-oleic and $\left[1-{ }^{14} \mathrm{C}\right]$-linoleic acid desaturation in cotton leaves. Physiol. Plantarum 69: 147-150.

25. Pham Thi AT, Da Silva JV, Mazliak P. 1990. The role of membrane lipids in drought resistance of plants. Bull de la Société Botanique de France. Actualités Botaniques. 137(1): 99-114.

26. Price AH, Atherton NM, Hendry GA. 1989. Plants under drought-stress generate activated oxygen. Free Radic. Res. Commun. 8: 61-66. 
27. Repellin A, Pham Thi AT, Tashakorie A, Sahsah Y, Daniel C, Zuily-Fodil Y. 1997. Leaf membrane lipids and drought tolerance in young coconut palms (Cocos nucifera L.) Europian J of Agron. 6:25-33.

28. Sahsah Y, Campos P, Gareil M, Zuily-Fodil Y, Pham-Thi AT. 1998. Enzymatic degradation of polar lipids in vigna unguiculate leaves and influence of drought stress. Physiologia Plantarum 104(4): 577-586.

29. Sattler SE, Cahoon EB, Coughlan SJ, DellaPenna D. 2003. Characterization of tocopherol cyclases from higher plants and cyanobacteria, evolutionary Implications for Tocopherol Synthesis and Function. Plant Physiol. 132:2184-2195.

30. Tanaka M, Murai M, Tokunaga H, Kimura T, Okada S. 1990. Tocopherol succinate reference standard (control 881) of National Institute of Hygienic Sciences. Eisei Shikenjo Hokoku 108: 156_158.

31. Toyoda T, Shi L, Takashu S, Cho YM, Kiriyama Y, Nikishawa A, Ogawa K, Tatematsu M, Tsukamoto T. 2016. Helicobacter 21(2): 131-142.

32. Xia J, Wishart D. 2016. Using metaboanalyst 3.0 for comprehensive metabolomics data analysis. Current Protocols in Bioinformatics 55: 14.10.11-14.10.91.

33. Yuan LJ, Qin Y, Zang Y, Chang H, Wang J, Wang B, Wan J, Chen SH, Zhang QY, Zhu JD, Zhou Y, Mi MT. 2016. Clinical Nutrition 35(2): 388-393. 